\title{
Pengaruh Frekuensi Penampungan Semen terhadap Konsentrasi dan Abnormalitas Spermatozoa Burung Puyuh
}

\author{
(THE INFLUENCE OF SEMEN FREQUENCY COLLECTION ON CONCENTRATION AND \\ SPERMATOZOA ABNORMALITIES OF QUAIL)
}

\section{Wayan Bebas $^{1 *}$, Komang Gita Permana ${ }^{2}$, I Gusti Ngurah Bagus Trilaksana ${ }^{1}$, Desak Nyoman Dewi Indira Laksmi ${ }^{1}$}
${ }^{1}$ Laboratorium Teknologi Reproduksi Veteriner, Fakultas Kedokteran Hewan Universitas Udayana, Denpasar-Bali. ${ }^{2}$ Dokter Hewan Paktek di Kabupaten Singaraja-Bali
*Email: w_bebas@unud.ac.id

\begin{abstract}
ABSTRAK
Penelitian ini bertujuan untuk mengetahui pengaruh frekuensi penampungan terhadap konsentrasi dan abnormalitas spermatozoa burung puyuh. Penelitian ini menggunakan rancangan acak lengkap (RAL) dengan 3 kelompok perlakuan, yaitu penampungan semen dengan interval pengambilan (hari) 2, 3 dan 4. Masing-masing perlakuan dilakukan pengulangan sebanyak 9 kali. Pengamatan dilakukan terhadap konsentrasi spermatozoa $\left(10^{7} \mathrm{sel} / \mathrm{ml}\right)$ dan abnormalitas spermatozoa (\%). Data yang diperoleh dianalisis dengan analysis of variance (ANOVA), apabila terdapat perberbedaan yang nyata $(\mathrm{P}<0,05)$ dilanjutkan dengan uji Duncan. Hasil penelitian menunjukkan konsentrasi spermatozoa pada masingmasing perlakuan adalah $39,00 \pm 5,148 \times 10^{7} \mathrm{sel} / \mathrm{ml} ; 59,49 \pm 1,878 \times 10^{7} \mathrm{sel} / \mathrm{ml} ; 59,11 \pm 2,028 \times 10^{7} \mathrm{sel} / \mathrm{ml}$. Abnormalitas pada masing masing perlakuan adalah 14,22 $1,394 \% ; 7,22 \pm 1,202 \% ; 7,49 \pm 1,130 \%$. Secara statistik frekuensi ejakulasi berpengaruh nyata $(\mathrm{P}<0,05)$ terhadap konsentrasi dan abnormalitas spermatozoa burung puyuh.
\end{abstract}

Kata kunci: frekuensi ejakulasi; konsentrasi; burung puyuh

\section{ABSTRACT}

The aims of this study are to determine the influence of collecting frequency against concentration and spermatozoa abnormalities of quail. This study used a completely randomized design (CRD) with 3 treatment groups, is collecting sement at 2, 3 and 4 days intervals. Each treatment is repeated 9 times. Observations were made on the concentration of spermatozoa (107 cells $/ \mathrm{ml})$ and abnormalities of spermatozoa $(\%)$. The data were analyzed using analysis of variance (ANOVA) if there are significantly different $(\mathrm{P}<0.05)$ followed by Duncan test. The results showed the concentration of spermatozoa in each treatment respectively $39.00 \pm 5.148 \times 107$ cells $/ \mathrm{ml} ; 59.49 \pm 1.878 \times 107$ cells $/ \mathrm{ml} ; 59.11 \pm 2.028$ x107 cells $/ \mathrm{ml}$. Abnormality in each treatment was $14.22 \pm 1.394 \% ; 7.22 \pm 1.202 \% ; 7.49 \pm 1.130 \%$. The frequency of ejaculation was statistically significant $(\mathrm{P}<0.05)$ against the concentration and spermatozoa abnormalities of quail.

Keywords: ejaculation frequency; concentration; quail

\section{PENDAHULUAN}

Burung puyuh merupakan salah satu jenis ternak unggas yang telah mengalami domestikasi, dan salah satu diantaranya adalah burung puyuh Japonica (Coturnix coturnix japonica) (Subekti dan Hastuti, 2013). Jenis puyuh ini yang paling popular diternakkan oleh masyarakat sebagai penghasil telur dan daging. Burung puyuh mulai dikenal dan dipelihara di Indonesia pada akhir tahun 1979. Perkembangan budidaya burung puyuh di Indonesia sudah semakin pesat, baik sebagai usaha komersil maupun usaha sampingan ini disebabkan karena meningkatnya kesadaran masyarakat akan kebutuhan protein hewani, serta diterapkannya teknologi modern tentang pemeliharaan (Siregar $e t$ al., 2007).

Indonesia dalam memenuhi bibit burung puyuh (Coturnix-coturnix japonica) masih mengimpor dari luar negeri seperti Taiwan, Hongkong dan Jepang. Kepentingan ini tentu saja membutuhkan dana yang tidak sedikit, sekaligus 
menimbulkan ketergantungan yang tinggi dari bangsa dan negara Indonesia terhadap negara lain. Pengembangan usaha peternakan burung puyuh yang baik maka membutuhkan bibit yang memadai ditinjau dari kualitas maupun kuantitas. Teknologi yang mampu mempercepat upaya peningkatan kualitas dan kuantitas ternak secara umum adalah teknologi inseminasi buatan, dan teknologi ini juga telah dipercaya dalam upaya konservasi satwa langka dan unggas langka (Piraksa dan Bebas 2009). Pada teknik inseminasi buatan, penampungan semen bertujuan agar memperoleh semen yang volumenya banyak dan kualitasnya baik untuk diproses lebih lanjut (Trilaksana et al., 2015).

Beberapa faktor yang mempengaruhi keberhasilan inseminasi buatan pada unggas adalah keberhasilan penampungan semen, tercampurnya semen dengan cairan yang keluar dari saluran reproduksi, konsentrasi spermatozoa yang diinseminasi dan waktu inseminnasi (Brillard, 1993). Menurut Zahraddeen et al. (2005) kualitas semen sangat dipengaruhi oleh musim, ras, umur, lamanya penyinaran, temperatur lingkungan, makanan, ukuran testes dan yang tidak kalah pentingnya adalah frekuensi ejakulasi (Bebas dan Laksmi, 2013). Semen burung puyuh ditampung dengan metode pemijatan yang diperkenalkan oleh Burrows dan Quinn pada tahun 1935.

Hasil penelitian pada domba ekor tipis yang dilakukan Widyaningrum (2006) menunjukkan bahwa frekuensi penampungan satu, dua, dan tiga kali dalam seminggu tidak memberikan pengaruh yang nyata terhadap warna, bau, konsistensi, $\mathrm{pH}$, motilitas, persentase hidup, dan abnormalitas spermatozoa. Bebas dan Laksmi (2013) melaporkan frekuensi ejakulasi pada ayam hutan hijau berpengaruh sangat nyata terhadap volume semen, konsentrasi permatozoa dan motilitas spermatozoa. Sedangkan penelitian yang dilakukan oleh Zahraddeen et al. (2005) pada kalkun frekuensi ejakulasi berpengaruh terhadap volume dan konsentrasi spermatozoa. Berdasarkan uraian di atas maka dilakukan penelitian untuk mengetahui pengaruh frekuensi penampungan terhadap konsentrasi dan abnormalitas spermatozoa burung puyuh.

\section{METODE PENELITIAN}

\section{Materi Penelitian}

Penelitian ini menggunakan 30 ekor burung puyuh umur 60 hari sebagai sumber semen. Burung puyuh dilatih mengeluarkan semen dengan metode pemijatan, sampai memberikan respon yang ditandai dengan keluarnya semen. Burung puyuh dipelihara dalam kandang bambu dengan ukuran $200 \times 75 \mathrm{~cm}$, diberikan pakan komersial (Comfeed Indonesia) sebanyak 22-23 gram per-hari, secara bertahap dua kali sehari (Subekti dan Hastuti, 2013).

Peralatan yang digunakan dalam penelitian antara lain: object glass, cover glass, pipet Pasteur, tabung Eppendorf 1 cc, mikroskop binokuler, tisu, kapas, haemocytometer, cawan petri, spuit $1 \mathrm{cc}$, counting chamber. Bahan-bahan yang digunakan dalam penelitian antara lain: pakan, air minum ad libitum, $\mathrm{NaCl} 3 \%$, semen puyuh, aquabidestilata, dan pewarna eosin negrosin sitrat.

\section{Metode Penelitian}

Rancangan yang digunakan dalam penelitian ini adalah rancangan acak lengkap yang terdiri dari tiga kelompok perlakuan kelompok I: semen ditampung interval 2 hari, kelompok II: semen ditampung interval 3 hari, kelompok III: semen ditampung interval 4 hari. Masingmasing kelompok perlakuan dilakukan pengulangan sebanyak 9 kali.

\section{Evaluasi Semen}

Konsentrasi spermatozoa dapat dihitung menggunakan haemocytometer dengan cara semen dihisap dengan pipet eritrosit (haemocytometer) sampai skala 0,5 . Selanjutnya hisap larutan $\mathrm{NaCl} 3 \%$ sampai skala 101. Kemudian ujung pipet ditutup dengan ibu jari dan jari tengah, lalu dihomogenkan dengan cara mengayunkan 
pipet menyerupai angka 8 . Buang beberapa tetes dan teteskan satu tetes di bawah kamar hitung. Sel sperma dihitung dalam 5 kamar hitung. Hasilnya dijumlahkan kemudian dikalikan dengan $10 \mathrm{juta} / \mathrm{ml}$. Pengamatan abnormalitas spermatozoa dilakukan melalui evaluasi morfologi spermatozoa dengan menggunakan pewarnaan eosin negrosin sitrat. Pemeriksaan ini dapat menentukan spermatozoa yang normal dan abnormal.

\section{Analisa Data}

Data yang diperoleh dianalisis menggunakan analysis of variance (ANOVA) selanjutnya dilakukan pengujian menggunakan uji one-way ANOVA. Bila terjadi perbedaan yang bermakna diantara perlakuan maka dilakukan uji lanjutan menggunakan Duncan (spss 17.0 for windows).

\section{HASIL DAN PEMBAHASAN}

Hasil rata-rata $(\mathrm{X} \pm \mathrm{SD})$ konsentrasi dan abnormalitas spermatozoa burung puyuh (Coturnix coturnix japonica) dapat dilihat pada Tabel 1. Setelah dianalisis menggunakan ANOVA menunjukkan bahwa frekuensi penampungan berpengaruh nyata $(\mathrm{P}<0,05)$ terhadap konsentrasi dan abnormalitas spermatozoa burung puyuh (Coturnix coturnix japonica). Uji lanjutan menggunakan
Duncan ternyata perlakuan T1 menghasilkan konsentrasi sperma yang nyata lebih rendah $(\mathrm{P}<0,05)$ jika dibandingkan dengan perlakuan T2 dan T3. Konsentrasi spermatozoa pada perlakuan T2 tidak menunjukkan perbedaan yang nyata $(\mathrm{P}>0,05)$ dengan perlakuan $\mathrm{T}$. Perlakuan T1 menghasilkan persentase abnormalitas yang nyata lebih tinggi $(\mathrm{P}<0,05)$ jika dibandingkan dengan perlakuan T2 dan T3. Persentase abormalitas spermatozoa pada perlakuan T2 tidak menunjukkan perbedaan yang nyata $(\mathrm{P}>0,05)$ dengan perlakuan $\mathrm{T} 3$.

Hasil penelitian, menunjukan bahwa frekuensi ejakulasi yang terlalu sering dalam satuan waktu yang terlalu pendek akan menurunkan konsentrasi spermatozoa per-ejakulasi. Hal ini sangat berkaitan dengan fungsi organ reproduksi unggas jantan dalam proses pembentukan spermatozoa (spermatogenesis), pengangkutan spermatozoa sepanjang saluran reproduksi, proses pematangan spermatozoa, dan penyimpanan spermatozoa. Proses spermatogenesis sebenarnya merupakan suatu proses yang berlangsung secara kontinyu selama masa produktif. Proses spermatogenesis terjadi di tubuli seminiferi, epididymis kemudian sperma menuju vas deferen (Bebas dan Laksmi, 2013).

Tabel 1. Rata-rata $(\mathrm{X} \pm \mathrm{SD})$ Konsentrasi dan Abnormalitas Spermatozoa Burung Puyuh (Coturnix coturnix japonica)

\begin{tabular}{|c|c|c|c|}
\hline \multirow{2}{*}{ Parameter } & \multicolumn{3}{|c|}{ Perlakuan } \\
\hline & $\mathrm{T} 1$ & $\mathrm{~T} 2$ & T3 \\
\hline Konsentrasi $10^{7}$ & $39.00 \pm 5.148^{\mathrm{a}}$ & $59.49 \pm 1.878^{b}$ & $59.11 \pm 2.028^{b}$ \\
\hline $\begin{array}{l}\text { Abnormalitas } \\
(\%)\end{array}$ & $14.22 \pm 1.394^{\mathrm{a}}$ & $7.22 \pm 1.202^{\mathrm{b}}$ & $7.49 \pm 1.130^{\mathrm{b}}$ \\
\hline Ulangan & 9 & 9 & 9 \\
\hline
\end{tabular}

Keterangan: huruf yang berbeda ke arah baris menunjukan perbedaan yang nyata $(\mathrm{P}<0,05)$. T1: penampungan semen dengan interval 2 hari; T2: penampungan semen dengan interval 3 hari; T3: penampungan semen dengan interval 4 hari.

Frekuensi ejakulasi sangat berpengaruh terhadap kualitas semen yang dihasilkan. Frekuensi ejakulasi 2 hari sekali (T1) menyebabkan penurunan konsentrasi spermatozoa, dan peningkatan persentase abnormalitas spermatozoa. Ini disebabkan ejakulasi merupakan proses pengeluaran semen dari tempat penampungan semen di bagian distal vas deferen yang berbatasan dengan kloaka baik secara kawin alam 
ataupun dengan teknik penampungan yang mengakibatkan terjadinya pengurangan atau pengosongan tempat penyimpanan. Apabila frekuensi ejakulasi terlalu sering jika dibandingkan dengan pengisiannya, maka akan terjadi penurunan volume semen dan penurunan konsentrasi spermatozoa (Bebas dan Laksmi, 2013).
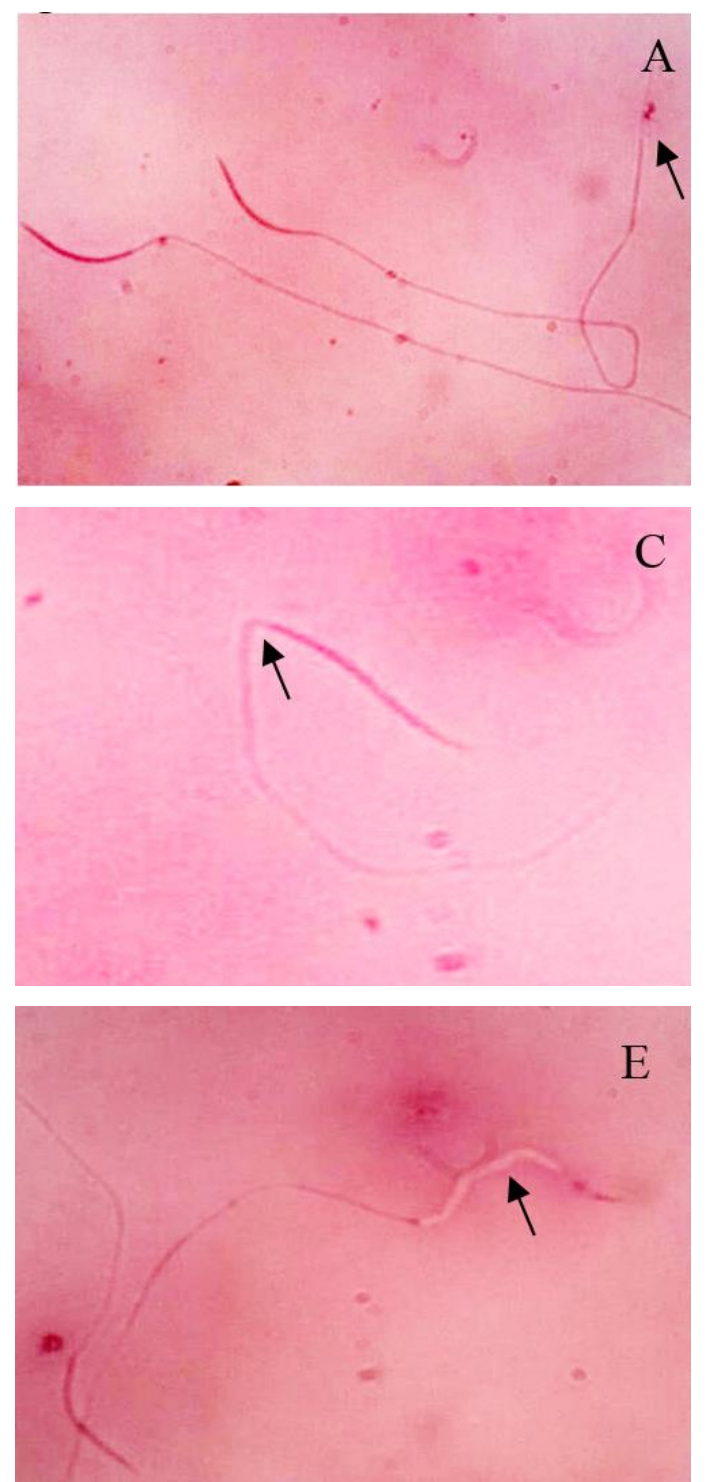

Menurut Yuwanta (1993) transport spermatozoa dari tubuli seminiferi sampai pada vas deferen mencapai 1-4 hari. Frekuensi ejakulasi yang semakin meningkat mengakibatkan banyak sel yang belum mengalami proses pematangan (immature) ikut terejakulasikan yang dapat mempengaruhi konsentrasi spermatozoa.
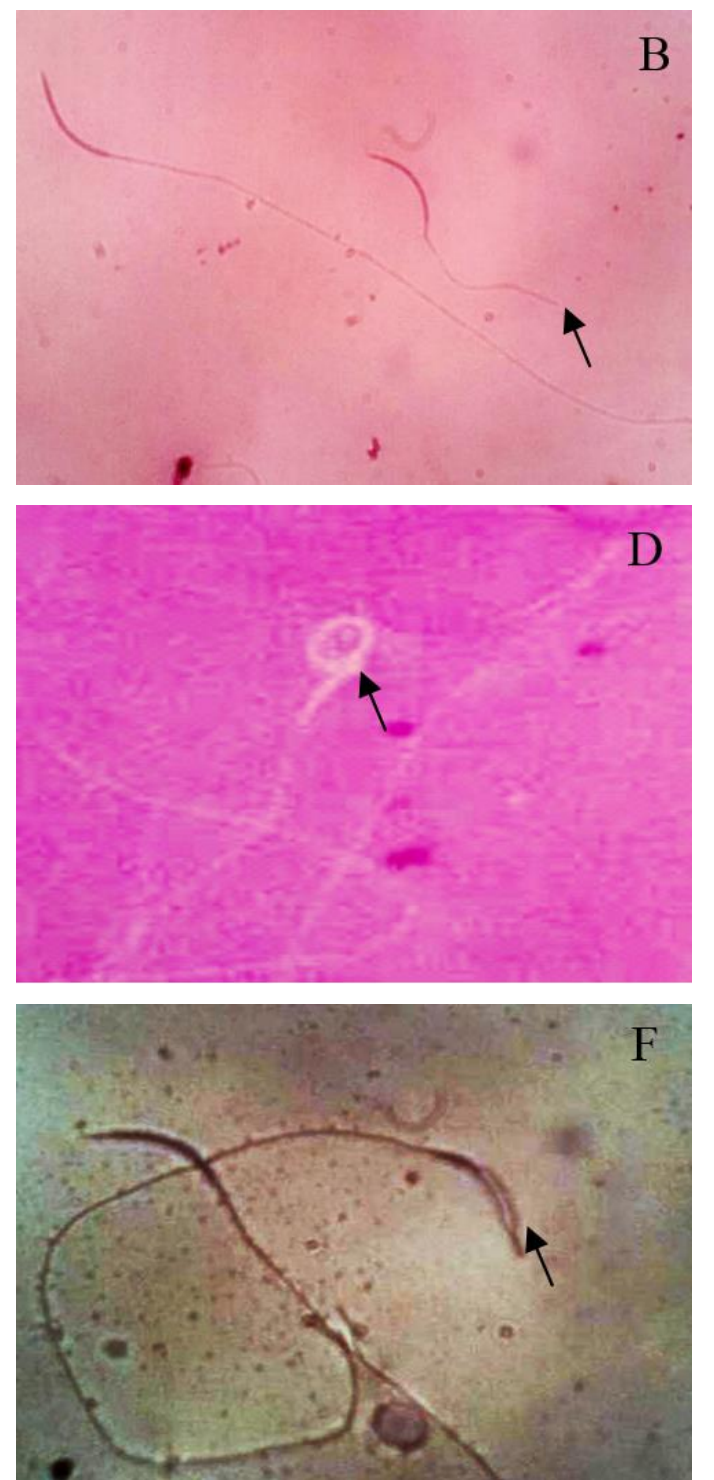

Gambar 1. Abnormalitas Spermatozoa burung puyuh (Eosin Negrosin Sitrat, 1000x). (A) Microchepalicl, (B) Broken tail, (C) Bent neck sperm abnormality, (D) Looped-head, (E) Macrocephalic, (F) Acrosome damage.

Pada perlakuan T2 dan T3 tidak berbeda nyata $(\mathrm{P}>0,05)$ terhadap konsentrasi spermatozoa, dan abnormalitas spermatozoa. Dengan frekuensi ejakulasi setiap 3 hari dan setiap 4 hari sudah memberikan kesempatan untuk proses transportasi, pematangan, dan penyimpanan sehingga kualitas semen berupa konsentrasi spermatozoa, dan abnormalitas spermatozoa menjadi lebih baik jika dibandingkan dengan $\mathrm{T} 1$. Perlakuan T1 menghasilkan persentase abnormalitas yang lebih tinggi $(\mathrm{P}<0,05)$ jika dibandingkan dengan perlakuan $\mathrm{T} 2$ dan T3. Abormalitas spermatozoa pada 
perlakuan $\mathrm{T} 2$ tidak berbeda nyata $(\mathrm{P}>0,05)$ dengan perlakuan T3.

Pada penelitian ini ditemukan abnormalitas spermatozoa berupa: bentuk microcephalic broken tail, bent neck sperm abnormality, looped-head, macrochepalic, dan acrosome damage (Gambar 1). Abnormalitas merupakan salah satu indikator dalam menentukan kualitas spermatozoa, karena struktur sel yang abnormal dapat menyebabkan gangguan dan hambatan pada saat fertilisasi, lebih jauh menyebabkan rendahnya angka implantasi maupun kebuntingan. Abnormalitas spermatozoa disebabkan abnormalitas primer, sekunder dan tersier. Abnormalitas primer biasanya terjadi pada tempat produksi spermatozoa yaitu tubuli seminiferi, sedangkan abnormalitas sekunder biasanya terjadi karena faktor transportasi spermatozoa dari tubuli semeniferi sampai terejakulasinya spermatozoa. Abnormalitas primer ditandai oleh kepala yang terlampau kecil (microcephalic) atau terlalu besar (macrocephalic), kepala yang lebar, ekor atau badan berganda. Abnormalitas sekunder ditandai dengan adanya butiran protoplasma pada pangkal ekor sperma tepatnya di caput epididymis. Abnormalitas tersier ditandai dengan ekor putus, ekor melingkar, dan kepala membesar yang disebabkan oleh faktor lingkungan (Danang et al., 2012).

Pada penelitian ini ditemukan abnormalitas spermatozoa berupa macrocephalic sperm (pembesaran pada kepala), looped-head (kepala melingkar), kerusakan akrosom, bent neck (penekukan pada leher), coiled tail (ekor melingkar), dan broken tail (ekor putus). Terdapat beberapa kriteria pada pemeriksaan spermatozoa. Kriteria tersebut antara lain: kepala berbentuk gelendong khas dan adanya akrosom (normal), kepala berbentuk bola (Bulb head/macrocephalic head), adanya patahan sel pada penghubung antara midpiece dan kepala (Bent-neck), kekurangan atau tidak adanya akrosom (kelainan akrosom), sel yang belum matang (Spermatid), warna kemerahan seluruh atau sebagian terwarnai oleh eosin (mati) (Chelmonska et al., 2007).

Abnormalitas burung puyuh yang diperoleh pada ketiga perlakuan dalam penelitian ini masing-masing adalah $14.22 \pm 1.394,7.22 \pm 1.202$ dan 7.49 \pm 1.130 . Jumlah abnormalitas pada penelitian ini tergolong lebih kecil dibandingkan laporan Chelmonska et al. (2008) yaitu sebesar $16 \%$. Hal ini diperkuat dengan pernyataan Saleh \& Sugiyatno $(2006 ; 2007)$ bahwa abnormalitas yang melebihi $20 \%$ jarang digunakan dalam pelaksanaan inseminasi buatan (IB). Abnormalitas spermatozoa dipengaruhi oleh umur dan lingkungan. Peninggian suhu udara karena kelembaban saat proses penampungan yang tinggi dapat menyebabkan kegagalan pembentukan dan penurunan produksi spermatozoa. Hal lain yang diduga penyebab periode penampungan menjadi berbeda sangat nyata adalah perlakuan terhadap spermatozoa pada saat percampuran dan pembuatan preparat ulas yang belum seragam sehingga abnormalitas berbeda (Nugroho dan Saleh, 2016).

Afiati et al. (2015) mengemukakan bahwa abnormalitas morfologi selalu ditemukan dalam setiap ejakulasi, namun mempunyai dampak yang berbeda terhadap fertilitas. Beberapa abnormalitas tertentu dapat menghambat pembuahan seperti kelainan kepala spermatozoa pear shape dapat mengganggu perkembangan embrio. Spermatozoa yang abnormal tidak mampu membuahi sel telur, meliputi round head, pin head, very large head, double head, abnormal midpiece, absent tail, dan double tails (Abbiramy dan Shanthi 2010). Penampungan yang terlalu sering dengan teknik masase mengakibatkan saluran reproduksi bagian leher seperti ampula vas deferen bagian posterior dan cloaca mengalami sedikit peradangan yang berdampak terhadap konsentrasi dan abnormalitas spermatozoa (Bebas dan Laksmi, 2013). Sehingga frekuensi 
penampungan dan evaluasi spermatozoa dari seekor pejantan harus rutin dilakukan.

\section{SIMPULAN DAN SARAN}

\section{Simpulan}

Frekuensi ejakulasi yang terlalu sering dalam satuan waktu yang terlalu pendek akan menurunkan konsentrasi spermatozoa per-ejakulasi serta peningkatan abnormalitas spermatozoa. Konsentrasi spermatozoa pada perlakuan T1, T2, dan T3 masing-masing $39,00 \pm 5,148 \times 10^{7} \mathrm{sel} / \mathrm{ml}$, $59,49 \pm 1,878 \times 10^{7} \mathrm{sel} / \mathrm{ml}, 59,11 \pm 2,028 \times 10^{7}$ $\mathrm{sel} / \mathrm{ml}$, dengan persentase abnormalitas $14,22 \pm 1,394 \%$, $7,22 \pm 1,202 \%$ $7,49 \pm 1,130 \%$.

\section{Saran}

Perlu dilakukan penelitian lebih lanjut tentang fertilitas spermatozoa burung puyuh dalam semen yang ditampung setiap tiga hari sekali

\section{UCAPAN TERIMA KASIH}

Penulis mengucapkan terima kasih kepada Bapak Dekan Fakultas Kedokteran Hewan dan Laboratorium Teknologi Reproduksi yang telah memberikan fasilitas pengggunaan Laboratorium sehingga penelitian ini bisa berjalan dengan lancar.

\section{DAFTAR PUSTAKA}

Abbiramy VS, Shanthi V. 2010. Spermatozoa Segmentation and Morphological Parameter Analysis Based Detection of Teratozoospermia. Int. J. Comp. Appl. 3(7): 19-23.

Afiati F, Yulnawati, Riyadi M, Arifiantini RI. 2015. Abnormalitas Spermatozoa Domba Dengan Frekuensi Penampungan Berbeda. Proc. Seminar Nasional Masyarakat Biodiversitas Indonesia. 1(4): 930-934.

Bebas W, Laksmi DNDI. 2013. Konsentrasi Spermatozoa dan Motilitas Spermatozoa Ayam Hutan Hijau (Gallus Varius). Bul. Vet. Udayana. 5(1): 57-62.
Brillard JP. 1993. Sperm Stroge and Transport Following Natural Mating and Artificial Insemination. Poultry Science, 72(5);117-143

Burrows WH, Quinn JP. 1937. The Collection of Spermatozoa from The Domestic Fowl and Turkey. Poult. Sci. 16(1): 19-24.

Chelmonska B, Jerysz A, Lukaszewich E, Malecki I. 2008. Semen Collection from Japanese Quail (Coturnix japonica) Using a Teaser Female. Turk. J. Vet. Anim. Sci. 32(1): 19-24.

Chelmonska B, Jerysz A, Lukaszewicz E, Kowalczyk A. 2007. The Effect of Proctodeal Gland Foam, and Depth and Frequency of Artificial Insemination on Fertility and Hatchability of Japanese Quail (Coturnix japonica). Turk. J. Vet. Anim. Sci. 31(3): 171-178.

Danang DR, Isnaini N, Trisunuwati P. 2012. Pengaruh Lama Simpan Semen Terhadap Kualitas Spermatozoa Ayam Kampung Dalam Pengencer Ringer's Pada Suhu $40^{\circ} \mathrm{c}$. Jurnal Ternak Tropika, 13(1):47-57

Nugroho AP, Saleh DM. 2016. Motilitas dan Abnormalitas Spermatozoa Ayam Kampung dengan Pengencer Ringer Laktat-Putih Telur dan Lama Simpan pada Suhu $5^{\circ} \mathrm{C}$ selama $48 \mathrm{Jam}$. Acta Vet. Indonesiana. 4(1): 35-41.

Piraksa IW, Bebas W. 2009. Pengaruh Penyuntikan Ekstrak Hipofisis Terhadap Berat Testes, Gambaran Mikroskopis Testes dan Kualitas Semen Ayam Hutan Merah (Galuus gallus). Bul. Vet. Udayana. 1(1): 13-19.

Saleh DM, Sugiyatno. 2006. Pengaruh waktu inseminasi buatan terhadap fertilitas ayam petelur. J. Produksi Ternak. 8: 83-87.

Saleh DM, Sugiyatno. 2007. Pengaruh aras glycerol terhadap motilitas dan abnormalitas spermatozoa ayam kampung yang dibekukan dengan nitrogen cair. J. Produksi Ternak. 9: 4548.

Siregar Z, Wahyuni TH, Chairani. 2007. Pengujian Suplementasi Mineral 
Esensial dalam Ransum Terhadap Fertilitas, Daya Tetas, Mortalitas dengan Perbandingan Jenis Kelamin Jantan dan Betina Puyuh. J. Agribisnis Peternakan. 3: 1-7.

Subekti E, Hastuti D. 2013. Budidaya Puyuh (Coturnix coturnix japonica) Di Pekarangan Sebagai Sumber Protein Hewani Dan Penambah Income Keluarga. Mediagro. 9(1):1-10.

Trilaksana I G N, Noviyati R N, Bebas W. 2015. Penambahan Vitamin C Pada Pengencer Fosfat Kuning Telur Semen Kalkun Yang Disimpan Pada Suhu $5^{\circ} \mathrm{C}$. Bul. Vet. Udayana. 7(2): 186-193.

Widyaningrum R, Ismaya, Keman S. 2006. Pengaruh frekuensi penampungan sperma terhadap kualitas sperma domba ekor tipis yang diencerkan dengan trisglucose-kuning telur dan dibekukan pada suhu- $196^{\circ} \mathrm{C}$. Bul. Peternakan. 30(2): 69-78.

Yuwanta T. 1993. Perencanaan dan Tata Laksana Pembibitan Unggas PTI, 683, Sub Bagian Inseminasi Buatan Pada Unggas. Skripsi. Program Studi Ilmu Ternak Pasca Sarjana Universitas Gadjah Mada, Yogyakarta.

Zahraddeen D, Butswat ISR, Kalla DJU, Sir SM, Bukar MT. 2005. Effect of Frequency of Ejaculation on Semen Characteristics in Two Breeds of Turkeys (Meleagris gallopavo) Raised in a Tropical Environment. Int. J. Poult. Sci. 4(4): 217-221. 